\title{
Maximizing Bali Village Tourism Potential Using Penta-Helix Model
}

\author{
Khusnul Rofida Novianti ${ }^{1 *}$ \\ ${ }^{1}$ Muhammadiyah University of Malang, Indonesia
}

\section{A R T I C L E I N F O}

Article history:

Received 26 December May 2020

Received in revised form

15 January 2021

Accepted 18 February 2021

Available online 25

February 2021

Keywords:

Sustainable Tourism, Penta-

Helix, Covid-19

\begin{abstract}
A B S T R A C T
The rapid growth of the tourism sector has made the government committed to implementing the principle of sustainable tourism development. To develop regional tourism, it is relatively necessary to direct, integrated, cross-sectoral, and sustainable programs so that the economic benefits of tourism are increasingly felt evenly distributed by the community. Bali, popular as one of the most tourist destinations in the world, is used as an example for the development of a national destination by the Indonesian government by creating 10 new Bali destinations, but this scheme must be postponed due to the covid-19 outbreak that hit Indonesia. This study aims to explore the sustainable tourism strategy in Bali's village tourism sector using a qualitative approach based on content analysis based on secondary data since Bali has the largest number of village tourism in Indonesia using the Penta-helix model (synergy between academic, business, community, government, and media). With the synergy and collaboration of these five central sectors (especially during decreasing tourism sector of coronavirus outbreak), it is expected to increase awareness and maximizing the potential among the public regarding Bali sustainable tourism.
\end{abstract}

Copyright (C) Universitas Pendidikan Ganesha. All rights reserved.

\section{Introduction}

The tourism sector is set as one of Indonesia's priority development programs in the President Joko Widodo agenda, Nawa Cita, and proclaimed as the leading sector contributing to GDP, foreign exchange and employment Indonesia's tourism sector contributes greatly to Indonesia's national economy. The tourism sector's contribution to the national Gross Domestic Product (GDP) in 2014 has reached $9 \%$ or as much as Rp 946.09 trillion (Kemenpar, 2018). The Indonesian tourism sector as the core economy with a projection of 2019 generates a foreign exchange of USS 24 billion beyond the oil and gas, coal and palm oil sectors. In addition, Indonesia's country branding with the "Wonderful Indonesia" tagline increase to rank 47 (previously ranked 100) defeating country branding truly Malaysia which reflects the positioning and differentiation of Indonesian tourism. Based on the World Economic Forum report, Indonesia's Travel and Tourism Competitiveness Index (TTI) rose from rank 70 in 2013 to 50 in 2015 and shot to rank 42 in 2017. At the end of 2019, it is estimated that Indonesia is ranked 30th in the world (Kemenpar, 2018).

The contribution of the tourism sector in the economy can be identified through tourist activities. Foreign tourists who come through the 20 main entrances in May 2019 amount to 951,214 people. This number has decreased from foreign tourists entering the previous month which amounted to 1,021,432 people. The performance of the Indonesian tourism sector is increasing, however compared to neighboring countries such as Malaysia, and Thailand which has less human and natural resources, the number of Indonesian visitors is far less as shown in the Figure 1. 


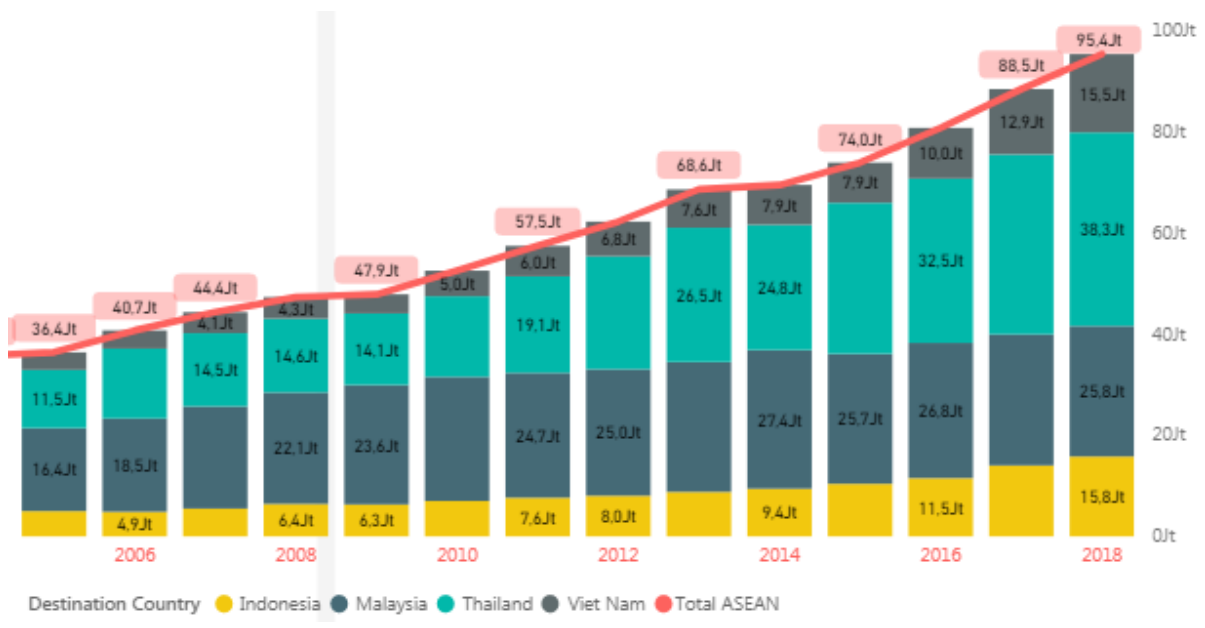

Figure 1. The ASEAN Visitor Arrival on Indonesia, Malaysia, Thailand, Vietnam 2006-2018 (www.data.aseanstats.org, 2020)

As the world's largest and one of the fastest-growing industries, tourism has been promoted as a feasible strategy for promoting international trade, economic development sustainability, and the best tool to alleviate poverty in the LDCs (Honeck, 2008; Scheyvens, 2007; UNWTO, 2006, 2007a, 2007b, 2008, 2009 , 2013). Sustainable development and sustainable tourism arguments naturally highlighted tourism as a viable and sustainable development strategy (COMCEC, 2013). The sustainable tourism development concept leads to several different tourism resource management models, alternative to mass tourism, including green tourism, rural tourism, nature-based tourism, heritage tourism, alternative tourism, low impact tourism, conscious tourism, fair trade tourism, soft tourism, appropriate tourism, quality tourism, responsible tourism, responsive tourism, ecotourism, pro-poor tourism, progressive tourism, sensitive tourism, and post-industrial tourism. Sustainable tourism is considered to be possible with such a healthy development (Aronsson, 2000). The 21st century started in favour of these new sustainable tourism models due to changes in tourist preferences (Lopez-Guzman et al, 2011). The approach to developing sustainable tourism was first introduced by the United Nations Environment and Development Commission. Sustainable tourism is the development of tourism activities aimed at meeting today's needs without jeopardizing the ability of natural resources to provide for future generations (Piartrini, 2018).

Due to the coronavirus outbreak in late 2019, the tourism sector all over the world has been falling down. Indonesia's economic activity partners in the first quarter of 2020 experienced a decline such as Singapore that experienced a decline of -2.2 percent, an EU country -2.7 percent, Hong Kong -8.9 percent and China experienced a decline of up to -6.8 percent. Often greatly affected is the United States of America. Economic growth has fallen by $2.3 \%$ to $0.3 \%$, South Korea by $2.3 \%$ to $1.3 \%$, Vietnam by $6.8 \%$ to $3.8 \%$, while Indonesia has fallen from $4.9 \%$ to $29 \%$. The closure of numerous tourism sector in Indonesia caused extreme problem, no exception of villages tourism in Bali. This problem affect to various groups, especially because Bali is an area that has the most tourist villages in Indonesia which has loss more than 85\% of its income (BPS Bali, 2018).

This study aims to identify and provide new insight to increase the potential of Bali tourism villages by using a strategic management approach, namely the Penta-helix model that rarely used especially in village tourism using a qualitative approach based on content analysis.

\section{Methods}

This paper using a qualitative approach using content analysis that common in the literature review as described by (Bengtsson, 2016). Secondary data obtained from the National Agency of Statistics of Bali and headquarter and Indonesian Ministry of Tourism that relevant to the sustainable tourism development, and Bali's village tourism as the main object. Content analysis is a research technique for making repricable and valid inferences from text (or other meaningful matter) to the context of their use (Krippendorff, 2004), and can be used in all types of data (written texts no matter where the material comes from) based on four stages, (1) the decontextualization (identify and familiarized data, this paper used keyword of sustainable tourism, village tourism, and Penta-helix in a reputable journal both national and international level, (2) recontextualization (compare with the original data, matching data based on the journal, statistical data, and other secondary data). (3) categorization (identify a homogenous group of 
topics or theme about sustainable tourism and Penta-helix), and (4) compilation, (draw a realistic conclusion about sustainable tourism strategy based on Penta-helix model application).

\section{Results and Discussions}

\section{Result}

\section{Bali's Tourism Sector}

Bali, well known as a popular tourist destination has its own charm, ranging from cultural tourism, maritime tourism, nature tourism, cultural heritage tourism, agrotourism, ecotourism (Choi et al., 2020; Sambou et al., 2019), sports tourism, rural area tourism (Astuti et al., 2018), and other tourism which ultimately makes Bali as a trendsetter for the formation of 10 New Bali (Balipost, 2019). Bali where philosophies are immersed in every detail of its way of life, it is evident for Bali to improve the development of tourism by linking to its philosophy (Hofstede, 2001). The tourism achievements of Bali Province are in line with the achievements of Indonesian tourism in the international world. Based on the World Economic Forum survey, Indonesia scored the value of Travel and Tourism Competitiveness Index (TTCI) of 4.2 percent and ranked 42 in the world up eight ranks from 2015 which only ranked 50. The contribution of the tourism sector, in this case, represented by the sub-sector providing accommodation and drinking food in the first quarter of 2019 GDP reached 23.28 percent and was the highest contribution compared to other sectors. The interest of foreign tourists to visit Bali continues to increase and is expected to continue to increase from year to year. An increase in the number of foreign tourists to Bali in 2018 compared to 2017 reached 6.54\%. Foreign tourists who come to Indonesia are dominant through I Ngurah Rai Airport as many as 485,758 people in May 2019 (BPS, 2019). According to nationality, the most recorded foreign tourists came to Bali in June 2019, namely tourists with Australian nationality (20.16\%), China (18.91\%), India (7.26\%), United Kingdom (4.83\%), and the United States 4.75\% (BPS Bali, 2019). An increase in the number of domestic tourists visiting each year.

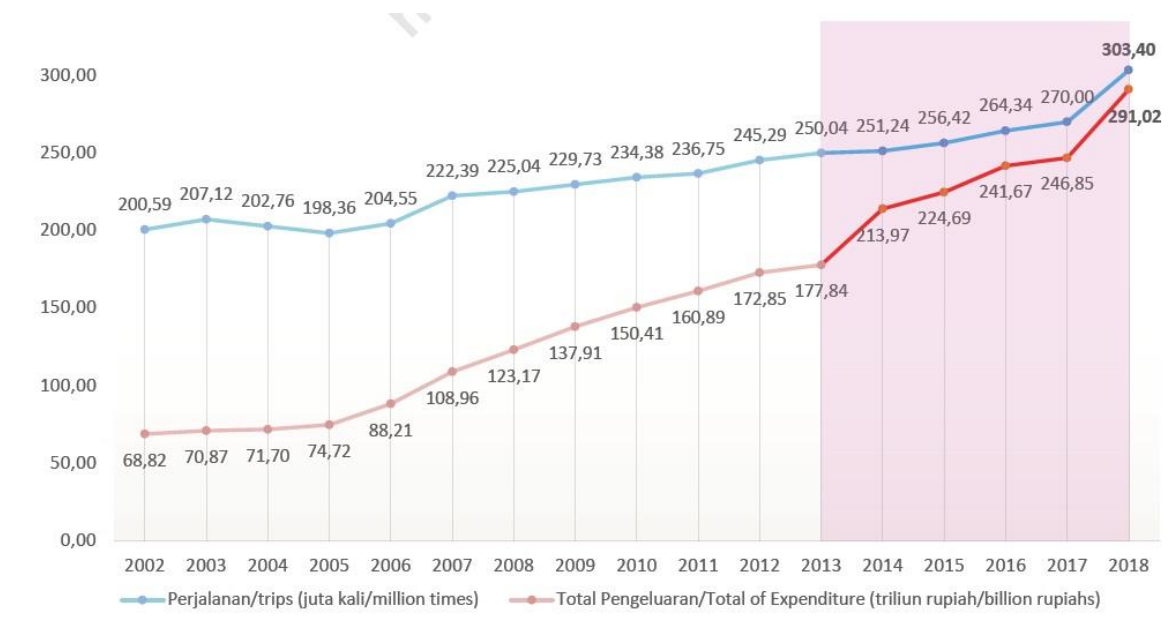

Figure 2. The Development of Local Tourist Visits to Bali, 2002-2018 (BPS, 2018)

The number of trips during 2018 reached 303.40 million trips, which means an increase of 12.37 percent compared to 2017 with a total of 270.00 million trips (BPS, 2018). Tourism development in the village has become a source of new economies while still adhering to cultural heritage. In general, tourist villages in Bali have a unique tradition and culture and are supported by a preserved environment. Bali has the most 110 villages tourism in Indonesia. The last calculation during 2018, experienced a graph of an increase of up to $124 \%$ compared to data collection four years ago. Bali Central Bureau of Statistics (BPS) also noted the number of villages with tourist objects increased by $32 \%$ in 2018 . The last calculation in 2018, there were 162 villages with tourism objects, which in 2014 were only 122 villages tourism. From the data, the village potential of 2018 is calculated by the Village Development Index (IPD) which shows the level of development of the village in the category of lagging, developing, or independent. 
Table 1. Total District and Village in Bali

\begin{tabular}{lcc}
\hline Regency / Municipality & District & Village / Sub-district \\
\hline Jembrana & 5 & 51 \\
Tabanan & 10 & 133 \\
Badung & 6 & 62 \\
Gianyar & 7 & 70 \\
Klungkung & 4 & 59 \\
Bangli & 4 & 72 \\
Karangasem & 8 & 78 \\
Buleleng & 9 & 148 \\
Denpasar City & 4 & 43 \\
\hline Total & $\mathbf{5 7}$ & $\mathbf{7 1 6}$ \\
\hline & & (BPS Bali, 2018)
\end{tabular}

\section{Discussion}

Sustainable development requires a process of economic and ecological integration through the formulation of paradigms and policy directions that rely on partnerships and participation of development actors in managing resources optimally (Baiquni, 2002; Nurhidayati, 2007). The Penta-helix model is a design of synergy between five sectors which are coordinated with each other. One of the strategies launched by the government in the development of tourism is through the use of the Penta-helix collaboration model. The Penta-helix Model was first launched by the tourism minister Arief Yahya and poured into the Republic of Indonesia Ministerial Regulation (Permen) Number 14 of 2016 concerning Sustainable Tourism Destination Guidelines that to create orchestration and ensure the quality of activities, facilities, services, and to create experience and value the benefits of tourism in order to provide benefits and benefits to society and the environment, it is necessary to encourage the tourism system through the optimization of the role of business, government, community, academic, and media (BGCAM). Penta-helix model is a reference in developing synergy between related agencies in optimally supporting in order to achieve goals. Pentahelix collaboration has an important role to play in supporting shared innovation goals and contributes to the socio-economic progress of the region (Soemaryani, 2016).

The first sector in the Penta-helix model is Academic. Academics in the Penta-helix model act as drafter or conceptor. They play a role in identifying the potential as well as product certification and human resource skills that support increasing the potential of the village (Yunas, 2019). The academic sector needs to prepare future leaders in the tourism industry who competence the sustainable tourism values through capacity building in human resources in order to make certified and standardized people and programs. Academicians have an obligation to carry out tri dharma activities (education, teaching, and service or social empowerment) that can be used as a means of developing sustainable tourism programs that can be adjusted and implemented in various sectors, one of which is a tourism village.

The second sector is the business. The private sector is an entity that carries out business processes in creating added value and maintaining sustainable growth (Yunas, 2019). Businesses can help by starting to maintain and improve health, especially from waste disposal so as not to damage the ecosystem which results in deterioration of the area around the business. The business sector has obligations for CSR (Corporate Social Responsibility) programs that need to be continued by starting to build ICT infrastructure that can be used by the public and the use of media as promotional efforts. The business sector can also begin to carry out assistance and facilitate programs such as communication and capacity building for village tourism managers.

The third sector is community, although sustainable tourism promotes community participation, protection, development (Ernawati et al., 2018), and improvement of the quality of life for all (France, 1998; Lea, 1988; Roseland, 2005), its top-down approach to distributing empowerment to stakeholders is considered an obstacle to collaborative community participation (Goodwin \& Santilli, 2009; Sebele, 2010). Local community need to take apart directly and indirectly (Amerta et al., 2018). The example application of community-based tourism (CBT) can be seen in the Village Ecotourism Village (Jaringan Ekowisata Desa (JED)) in Bali (COMCEC, 2013). JED was initiated in 2002 as a community-based tourism project by the network of four Balinese village communities, under the guidance of the environmental Balinese NGO, the Wisnu Foundation. The villages in the network were Kiadan Pelaga, Hamlet Sibetan, Tenganan Pegrisingan, and Ceningan Island. The main offer of this initiative is the traditional Balinese way of life, local farming practices, dance, art and craft production, and local cuisine. In this case, the community is people who have the same interests and are relevant to the potential development that will be developed (Yunas, 2019). Indigenous tourism, underpinned by the principles of sustainable development, arguably 
provides opportunities to realize unique, often innovative, developments or management approaches that can be very beneficial to Indigenous peoples (Carr 2016).

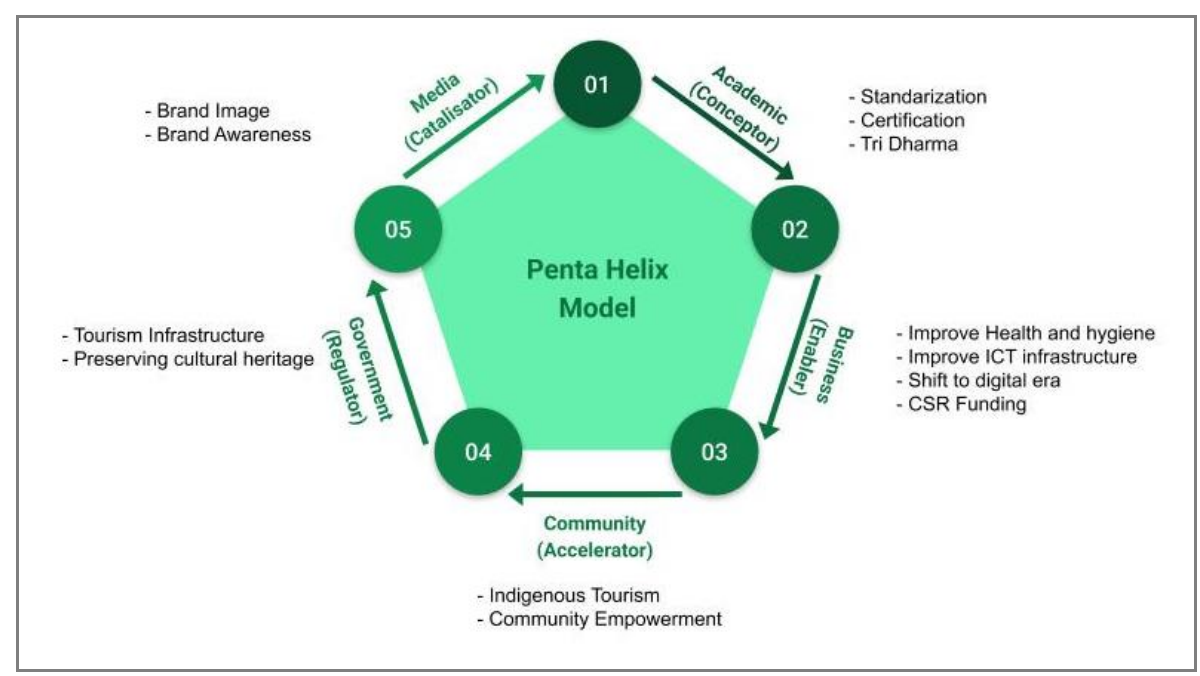

Figure 3. The Penta-helix model in Bali Tourism Village

The government must act as a regulator and act as a controller that has regulations and responsibilities in developing businesses. In this case, it involves all types of activities such as planning, implementation, monitoring, controlling, promotion, financial allocation, licensing, programs, laws, development and knowledge, public innovation policies, support for innovation networks and publicprivate partnerships (Yunas, 2019). Government The government acts as a regulator that is able to make policies, allocation of funds and stakeholders that can help advance the tourism sector, one of which is through the improvement of tourism infrastructure. The government also needs to make policies and regulations related to protecting the original cultural area which is unique to Bali's tourism sector. Provincial Government of Bali in an effort to strengthen the local culture of Tri Hita Karana, the life of Balinese society that build balance of the relationship betweeen God, human, and human being such as the Pakraman Village (Wisnumurti \& Rideng, 2017).

The last sector is media. The media sector acts as a catalyst that plays a role in the branding image of local tourism and branding awareness for Bali tourism villages through various promotional activities in all media (both social media, mass media, and other media). This five sector need to work together and collaborate in developing sustainable tourism programs. The benefits of this collaboration is increasing awareness among the public regarding tourism, touristic products, and its benefits, increased tourist arrivals and profits from tourism activities and involvement of local farmers into the tourism workforce as guides, cooks, and home-stay owners.

\section{Conclusion}

The emergence of the Pandemic Covid-19 outbreak has led to the disruption of Indonesia's economic sector, especially in the tourism sector. The concept of sustainable tourism development is one of the main agendas of the government which is the leading sector of the Indonesian economy. The Penta Helix collaboration which is a collaborative activity between lines/fields of Academic (conceptor), Business (enabler), Community (accelerator), Government (regulator), and Media (catalisator), otherwise known as ABCGM is known to accelerate the development of tourism development potential including village tourism. This result contributes to the literature development about the strategic approach in tourism sector using Penta-helix model and give some insight about how to manage sustainable tourism using the synergy and collaboration between five main sectors in Indonesia.

\section{References}

Amerta, I. M. S., Sara, I. M., \& Bagiada, K. (2018). Sustainable tourism development. International Research Journal of Management, IT \& Social Sciences, 5(2), 248-254. https://doi.org/10.37040/geografie2001106030178.

Aronsson, L. (2000). The development of sustainable tourism. Continuum. 
ASEAN Statistics. (2020). ASEAN Visitor Arrivals Dashboard. ASEAN Statistics Division. https://data.aseanstats.org/dashboard/tourism.

Astuti, N. N. S., Ginaya, G., \& Susyarini, N. P. W. A. (2018). Designing Bali tourism model through the implementation of tri hita karana and sad kertih values. International Journal of Linguistics, Literature and Culture, 5(1), 12-23. https://doi.org/10.21744/ijllc.v5n1.461.

Baiquni, M. (2002). Integrasi Ekonomi dan Ekologi dari Mimpi Menjadi Aksi. Wacana III, 12 (3).

Bengtsson, Mariette. 2016. How to Plan and Perform a Qualitative Study Using Content Analysis. NursingPlus Open, 1(2), 8-14. https://doi.org/ 10.1016/j.npls.2016.01.001.

BPS. (2018). Statistik Potensi Desa Provinsi Bali. Badan Pusat Statistik. https://bali.bps.go.id/publication/2018/12/26/2b998cd416941170b5e367a8/statistik-potensidesa-provinsi-bali-2018.html.

BPS. (2018). Statistik Wisatawan Mancanegara ke Bali. Badan Pusat Statistik. https://bali.bps.go.id/publication/2019/07/25/8c3d5ec92c9b931594a186d8/statistikwisatawan-mancanegara-ke-bali-2018.html.

BPS. (2018). Statistik Wisatawan Nusantara. Badan Pusat Statistik. https://www.bps.go.id/publication/2019/07/02/5249c2b645e21291b51dfc1a/statistikwisatawan-nusantara-2018.html.

BPS. (2019). Jumlah Kunjungan Wisman ke Indonesia Juni 2019. Badan Pusat Statistik. https://www.bps.go.id/pressrelease/2019/08/01/1615/jumlah-kunjungan-wisman-keindonesia-juni-2019-mencapai-1-45-juta-kunjungan-.html.

Carr, A., Ruhanen, L., \& Whitford, M. (2016). Indigenous peoples and tourism: the challenges and opportunities for sustainable tourism. Journal of Sustainable Tourism, 24(8-9), 1067-1079. https://doi.org/10.1080/09669582.2016.1206112.

Choi, G., Kim, J., Sawitri, M. Y., \& Lee, S. K. (2020). Ecotourism market segmentation in Bali, Indonesia: Opportunities for implementing REDD+. Land, 9(6), 1-15. https://doi.org/10.3390/LAND9060186.

Ernawati, N. M., Sudarmini, N. M., \& Sukmawati, N. M. R. (2018). Impacts of Tourism in Ubud Bali Indonesia: A community-based tourism perspective. Journal of Physics: Conference Series, 953(1). https://doi.org/10.1088/1742-6596/953/1/012078.

France, L. (1998). Local participation in tourism in the West Indian Islands. In Laws, E., Faulkner, B., and Moscardo, G. (Eds.), Embracing and Managing Change in Tourism (pp. 223-224). Routledge.

Hofstede, G. (2001). Culture's consequences: Comparing values, behaviors, institutions and organizations across nations. Sage publications

Honeck, D. (2008). LDC Poverty Alleviation and the Doha Development Agenda: Is Tourism being Neglected? World Trade Organization Economic Research and Statistics Division.

Kemenpar. (2018). Laporan Akhir Kajian Dampak Sektor Pariwisata terhadap Perekonomian Indonesia. Kementerian Pariwisata Republik Indonesia. www.kemenpar.go.id/.../media_1554437393_Laporan_Akhir.pdf.

Krippendorff, K. (2004). Content Analysis: An Introduction to Its Methodology. Sage Publications Inc.

Lea, J. (1988). Tourism Development in the Third World. Routledge.

López-Guzmán, T., Borges, O., \& Castillo-Canalejo, A. M. (2011). Community-based tourism in Cape Verde-a case study. Tourism and Hospitality Management, 17(1), 35-44. https://hrcak.srce.hr/6922.

Nurhidayati, S. E. (2007). Community Based Tourism (CBT) sebagai pendekatan pembangunan pariwisata berkelanjutan. Jurnal Masyarakat, Kebudayaan, dan Politik, Th. XX, (3), 191-202. http://www.journal.unair.ac.id/filerPDF/abstrak_214715_tpjua.pdf.

Piartrini, P. S. (2018). The Relationship Among Community Based Tourism Application, Community Attitude, Community Empowerment, and Community Life Satisfaction. E-Journal of Tourism, 5(2), 130-143.

https://pdfs.semanticscholar.org/0bf8/b992464da57db66c00ce6ad96e042008869a.pdf. 
Roseland, M. (2005). Towards Sustainable Communities: Resources for Citizen and Their Governments. New Society Publishers.

Sambou, O., Riniwati, H., \& Fanani, Z. (2019). Socio-economic and Environmental Sustainability of Ecotourism Implementation: A Study in Ubud Monkey Forest-Bali, Indonesia. Journal of Indonesian Tourism and Development Studies, 7(3), 200-204. https://doi.org/10.21776/ub.jitode.2019.007.03.09.

Scheyvens, R. (2007). Exploring the tourism-poverty nexus. Current issues in tourism, 10(2-3), 231-254. https://doi.org/10.2167/cit318.0.

Sebele, L.S. (2010). Community-based Tourism Ventures, Benefits and Challenges: Khama Rhino Sanctuary Trust, Central District, Botswana. Tourism Management, 31(1): 136-146. https://doi.org/10.1016/j.tourman.2009.01.005.

Soemaryani, I. (2016). Pentahelix model to increase tourist visit to bandung and its surrounding areas through human resource development. Academy of Strategic Management Journal, 15, 249-259. https://search.proquest.com/openview/091494ef547e622a456cf0dd2210d17a/1?pqorigsite=gscholar\&cbl $=38745$.

Tasci, A. D., Semrad, K. J., \& Yilmaz, S. S. (2013). Community basted tourism: Finding the equilibrium in the COMCEC context. COMCEC Coordination Office

UNWTO. (2006). Tourism and Least Developed Countries: A Sustainable Opportunity to Reduce Poverty. UN World Tourism Organization.

UNWTO. (2007a). UNWTO Development Assistance - Annual Report of the World Tourism Organization on Development Assistance Activities. UN World Tourism Organization. http://dtxtq4w60xqpw.cloudfront.net/sites/all/files/pdf/unwtodevelopmentassistance08.pdf.

UNWTO. (2007b). ST-EP Programme- Sustainable Tourism - Eliminating Poverty: An Initiative of the World Tourism Organization (UNWTO) in conjunction with the UNWTO ST-EP Foundation. UN World Tourism Organization. http://step.unwto.org/sites/all/files/docpdf/st-epbooklet2007.pdf.

UNWTO. (2008). UNWTO Development Assistance - Annual Report of the World Tourism Organization on Development Assistance Activities. UN World Tourism Organization. http://dtxtq4w60xqpw.cloudfront.net/sites/all/files/pdf/unwtodevelopmentassistance08.pdf.

UNWTO. (2009). Tourism Contributing to Poverty Alleviation. UN World Tourism Organization. http://step.unwto.org/sites/all/files/docpdf/tourismcontributingtopoverty alleviation2009.pdf.

UNWTO. (2012). Tourism Highlights, 2012 Edition. UN World Tourism Organization. http://dtxtq4w60xqpw.cloudfront.net/sites/all/files/docpdf/unwtohighlights12enhr_1.pdf.

UNWTO. (2013). Report of the World Tourism Organization to the United Nations Secretary-General in preparation for the High Level Meeting on the Mid-Term Comprehensive Global Review of the Programme of Action for the Least Developed Countries for the Decade 2001-2010. UN World Tourism Organization. http://www.un.org/special-rep/ohrlls/ldc/MTR/WorldTourisminput.pdf.

Wisnumurti, A. A. G. O., \& Rideng, I. W. (2017). The Development of Bali Tourism Through Cultural and Local Wishdom of Pakraman Village. Journal of Tourismology, 3(2), 38-43. https://dergipark.org.tr/en/pub/iuturizmoloji/issue/36431/413893.

Yunas, Novy Setia. (2019). Implementasi Konsep Penta-Helix Dalam Pengembangan Potensi Desa Melalui Model Lumbung Ekonomi Desa di Provinsi Jawa Timur. Matra Pembaruan Jurnal Inovasi Kebijakan 3 (1) 37-46. https://doi.org/10.21787/mp.3.1.2019.37-46. 